\title{
The Effectiveness of Multimedia Application on Students Listening Comprehension
}

\author{
Tagor Pangaribuan ${ }^{1}$, Andromeda Sinaga ${ }^{1} \&$ Kammer Tuahman Sipayung ${ }^{1}$ \\ ${ }^{1}$ English Department, University of HKBP Nommensen, Indonesia \\ Correspondence: Tagor Pangaribuan, English Department, University of HKBP Nommensen, Sutomo St. No.4A, \\ Medan, Indonesia. Tel: 62-(061)-457-8135. E-mail: tagorp52@yahoo.com
}

Received: September 20, 2017 Accepted: November 20, 2017 Online Published: November 23, 2017

doi: 10.5539/elt.v10n12p212 URL: http://doi.org/10.5539/elt.v10n12p212

\begin{abstract}
Listening comprehension is a complex skill particulaly in mastered by non-native speaker settings. This researchaimed atfinding out the effect of multimedia application on students' listening. The research design is experimental, with a t-test. The population is the sixth semester of HKBP Nommensen University at the academic year of 2016/2017, six classes of listening comprehension, 3 classes for experiemnts and the other for control, each class of 20 students. The findings states that the Tcount $=14.68>$ Ttable $=2.02$ in $\alpha$ significance 0.05 and degree of freedom 38. It means that, multimedia aplication is effective than conventinal media. Multimeadi in this study can be used by other lecturer or teacher as the optional instrument in teaching listening comprehension.
\end{abstract}

Keywords: effectiveness, multimedia, listening comprehension

\section{Introduction}

Listening is one of the toughest skills among the four language skills in English such as listening, speaking, reading and writing and the most challenging skills as well. Listeners learns to discriminate between sounds, understand vocabulary and grammatical structures, interpret stress and intention, retain and interpret this within the immediate as well as the larger socio-cultural context of the utterance defines listening, in its broadest sense, as a process of receiving what the speaker actually says (receptive orientation); constructing and representing meaning (constructive orientation); negotiating meaning with the speaker and responding (collaborative orientation); and, creating meaning through involvement, imagination and empathy (transformative orientation).

Listening is a complex, active process, of interpretation in which listeners match what they hear with what they already know. Although listening is now well recognized as a critical dimension in language learning, it still remains one of the least understood processes. During the 1980's listening was treated as an instructional subject (Moreley 2001), in functional communicative framework. Throughout the 1990s, attention to listening in language instruction increased, and now is an important language learning competence (Morley, 2001).

The importance of listening is emphasized (Richards, 2008, Nunan, 1998; Nation and Newton, 2009) and now it is a core course in many language programs. Even so, the fact is that students' listening comprehension competence is not satisfactory or low. Based on the researchers' experience on teaching listening comprehension, most of students (sixth semester) are lack on this skill. The researchers as lectures used the conventional media such as tape recoder as the main instrument in teaching listening. The lecturers must replay the dialogue manualy and the sound is blurr in teaching process. Through this phenomenon, the researchers have a great desire to conduct an experimental research by applying the multimedia application on teaching listening process. The researchers assumed that multimeadia applicatioan has a significant effect than conventional media in teaching listening process. This is the reason of researchers to make it become an issue in this study. The researchers would like to know whether multimedia treatment significantly effect on listening comperehension or not. This research is focussed on the use of multimedia in listening comprehension. Multimedia Application is limited to the CD-ROM software which is designed by the researcher to help the lecturer in providing the listening materials. This research will challenge to what extent teaching reflection help the generic process in teaching and learning listening compehenson. 


\section{Related Literature}

\subsection{Media Play}

Media play a number of roles in education that have to do with communication and instrumentation. These roles fall into three categories: (a) the delivery of instruction, in which media are used to convey specific content, (b) the construction of mediated environments, in which media help students explore and construct understanding of a body of knowledge, and (c) the development of cognitive skills, where media are used to model, engender, or extend mental skills. Three types of theory support these roles of media. Semiotic theories are concerned with how media represent what they refer to. Cognitive theories account for how students decode and learn from the messages media convey. Contextual theories are concerned with learning contexts that media create. This entry describes the three educational roles that media play, reviews the three types of theory, and discusses issues that arise from the roles and theories. This entry includes by identifying current trends that are likely to shape the future of the way media are used in education.

Since the mid-1970s educators have become increasingly sensitive to the need to select media on the basis of their instructional function (Heidt, 1976). Consequently, the role media play in instruction is determined from a careful analysis of the goals and content that students are expected to master, and from an analysis of the students themselves. The selection or design of the mediated portions of instruction is therefore guided by knowledge of which media are the most effective for delivering which kinds of content to which kinds of students.

An increasingly important role for media in the delivery of instruction is in distance education. Telecommunications and related technologies have been used in large and modest projects in many countries to deliver instruction. The United Kingdom's Open University is a good example of a large-scale project and exemplifies many of the characteristics of mediated distance education. University courses are delivered by correspondence, radio, and television to students' homes. The Satellite Instructional Television Experiment (SITE) in India is typical of mediated distance education in developing countries. Programs in basic education, agriculture, and health care are broadcast to communities around the country in a variety of languages. Members of local communities are involved in many aspects of the project. Most recently, educators have become interested in using the Internet and the World Wide Web for teaching and learning (Dyrli and Kinnaman, 1995). With the potential for affecting a marriage between multimedia and distance education technologies, the Web is used primarily by lecturers and students as a rich source of information in many formats (multimedia).

Technology is increasingly becoming a part of the English classroom as an instructional and research aid for lecturers and students. Many questions arise from the application of multimedia in a classroom of English subject. Do the students need multimedia application to learn English more? Does multimedia application improve the students' listening comprehension? Does the lecturer change the learning process to the students? Is multimedia application effective, efficient and challenging for the students in learning English? Does the lecturer teach English with multimedia effectively? Do the students understand how to use the multimedia? Does the environment support the learning process with multimedia? In this study, the researcher would like to improve the students' listening comprehension as a part of the four language skills in an English classroom lesson.

When learning with multimedia, the brain must simultaneously encode two different types of information, an auditory stimulus and a visual stimulus. One might expect that these competing sources of information would tend to overwhelm or overload the learner. However, psychological research has shown that verbal information is in fact better remembered when accompanied by a visual image. Baddeley and Hitch proposed a theory of working memoryin 1974 which has two largely independent subcomponents that tend to work in parallel - one visual and one verbal/acoustic. This allows learners to simultaneously process information coming from their eyes and ears.

\subsection{The Hierarchy of Multimedia}

Multimedia is media and content that uses a combination of different content forms. The term can be used as a noun (a medium with multiple content forms) or as an adjective describing a medium as having multiple content forms. The term is used in contrast to media which only use traditional forms of printed or hand-produced material. Multimedia includes a combination of text, audio, images, animation, video, and interactivity content forms.In common usage, the term multimedia refers to an electronically delivered combination of media including video, still images, audio, text in such a way that can be accessed interactively. Much of the content on the web today falls within this definition as understood by millions. Some computers which were marketed in the 1990s were called "multimedia" computers because they incorporated a CD-ROM drive, which allowed for the delivery of several hundred megabytes of video, picture, and audio data. 
Multimedia is usually recorded and played, displayed or accessed by information content processing devices, such as computerized and electronic devices, but can also be part of a live performance. Multimedia (as an adjective) also describes electronic media devices used to store and experience multimedia content.Multimedia is distinguished from mixed media in fine art; by including audio, for example, it has a broader scope. The term "rich media" is synonymous with interactivemultimedia. Hypermedia can be considered one particular multimedia application.

Multimedia may be broadly divided into linear and non-linear categories. Linear active content progresses without any navigational control for the viewer such as a cinema presentation. Non-linear content offers user interactivity to control progress as used with a computer game or used in self-paced computer based training. Hypermedia is an example of non-linear content.Multimedia presentations can be live or recorded. A recorded presentation may allow interactivity via a navigation system. A live multimedia presentation may allow interactivity via an interaction with the presenter or performer.Multiple forms of information content are often not considered modern forms of presentation such as audio or video. Likewise, single forms of information content with single methods of information processing (e.g. non-interactive audio) are often called multimedia, perhaps to distinguish static media from active media.

\subsection{The Hierarchy of Listening Comprehension}

Listening is not simply hearing or perceiving definitions, that listening is an active process involving four interrelated activities: receiving aural stimuli, attending to the spoken words, attaching meaning to the aural symbols, and responding to oral communication (Postovsky, 1977). The section has presented some proposed definitions of the word "listening". Listening implies more than just perception of sound; a listening process also requires an act of attending to the speech sounds and trying to understand the message. Listening is not a passive process, not a passive skill but it requires full participation and the undivided attention of the learners to acquire it (Clark, 2000; Richards, 1983). The nature of the skill is a complex process and construct (Vandergrift, 1999). It is a complex, active process in which the listener must discriminate between sounds, understand vocabulary and grammatical structures, interpret stress and intonation, retain what was gathered in all of the above, and interpret it within the immediate as well as the large socio-cultural content of the utterance. Coordinating all of this involves a great deal of mental activity on the part of the listener. Listening is hard work, and deserves more analysis and support".

Listening comprehension does not require learners to apply only linguistic knowledge. Rather, it is actually an active process, which listeners have to function by synchronously employing both linguistic knowledge and non-linguistic knowledge, while receiving messages, in order to create meaning. The meaning constructed will largely depend upon the individual background history of each listener. Therefore, each listener will also deal with the listening passage differently. As stated before, listening is an interactive process that involves both the process of the receiving of sound waves (audible symbols) and the process of the brain's acting on the nerve impulses, employing the operation of various complicated cognitive and affective mechanisms interactive model of listening comprehension which elaborates on eight mental operations involved supply an answer to the question "what are listeners doing when they listen".

1) The hearer processes what we'll call "raw speech" and holds an "image" of it in short-term memory. This image consists of the constituents (phrases, clauses, cohesive markers, intonation, and stress patterns) of a stream of speech.

2) The hearer determines the type of speech event that is being processed. The hearer must, for example, ascertain whether this is a conversation, a speech, a radio broadcast, etc., and then appropriately "colour" the interpretation of the perceived message.

3) The hearer infers the objectives of the speaker through consideration of the type of speech, the context, and content. So, for example, one determines whether the speaker wishes to persuade, to request, to exchange pleasantries, to affirm, to deny, informing and so forth. Thus the function of the message is inferred.

4) The hearer recalls background information (or schemata) relevant to the particular context and subject matter. A lifetime of experiences and knowledge are used to perform cognitive association in order to bring a plausible interpretation to the message.

5) The hearer assigns a literal meaning to the utterance. This process involves a set of interpretations of the surface strings that the ear has perceived.

6) The hearer assigns an intended meaning to the utterance (in many instances, perceived and intended meanings match). 
7) The hearer determines whether information should be retained in short-term or long-term memory. Short-term memory - a matter of a few sounds - is appropriate, for example, in contexts that simply call for a quick oral response from the hearer. Long-term memory is more common when, say, information in a lecture is being processed. There are, of course, many points, in between.

8) The hearer deletes the form in which the message was originally received. The information is retained conceptually. With the exception of the initial and final processes, no sequence is implied here; they all occur, if not simultaneously, then in extremely rapid succession. Neurological time must be viewed in terms of microseconds.

Listening comprehension often plays only a trivial role in foreign language teaching and learning environments despite the fact that it often figures prominently in curricular guidelines and statements of objectives. It is always included as one of the main objectives in the curriculum that students need to acquire but in practice it usually receives little attention.In fact, listening skills are very important but relatively few research projects are carried out in this area. In addition, it is widely believed that listening skills are enabling skills that can happen on their own. Some lecturers also believe that if students are efficiently taught and trained in reading and speaking skills, they would acquire these skills and as a consequence their listening skill will be improved too. It is clear that listening comprehension is an essential skill to be acquired and should not be taken for granted in the foreign or second language teaching and learning environment. The ability to listen cannot be transferred from teaching of other skills. In order to prevent listening comprehension from being treated like the 'Cinderella' skill, as, listening comprehension should be given time and attention in the classroom and this should be done from the very beginning and throughout the students' academic lives. It should not be treated as a by-product skill in the learning environment.

\section{Methodology}

The research design design is a quantitatve t-test with classroom-action research as its treatment. This design was used to know the effect of multimedia application. This research design isto find out to what extent the multimedia application helps improve the mastery of listening comperehsnion, as follows.

\begin{tabular}{llll}
\hline & Pre-test & Treatment & Post-Test \\
\hline Control Group (A) & $\sqrt{ }$ & Without Multiedia Application & $\sqrt{ }$ \\
Experimental Group (B) & $\sqrt{ }$ & Using Multiedia Application & $\sqrt{ }$ \\
\hline
\end{tabular}

Pre-test are given to both of groups (experimental and control), but in teaching and learning process both of groups had difference treatment (experience) whether experimental group are taught with multimedia application while control group with conventional way or without multimedia application. At the end of this design, both of group are given the post-test. Finally the data (pre-test and post-test) was analyzed with t-test and compare with t-table.

\section{Result and Discussion of Research}

The research findings states that there is a significant $T_{\text {count }}=14.68>T_{\text {table }}=2.02$. the observation and teaching reflection says that a teacher the use of multimedia need to adjust and sometimes rewind the use of multimedia to enhance and to help facilitate imputs for the listening and to give time to accomodate new-old information strategy to enhance the process of listening comprehension capacity and aquisition. It happened that when a students has master at listening comprehension discourse material, he needs more practices of similar text generic content so that the logical spot capacity grows better upon further listening comprehension disourse. The need analysis shows that sentece extent the discourse material of listening materials is relevant to the need of the learners as the table below depicted it. 
Table 1. Need analysis data

\begin{tabular}{llll}
\hline Information Type & Answer & Frequency & Need Percentage (\%) \\
\hline $\begin{array}{l}\text { Have recognized or haven't recognized about } \\
\text { interactive multimedia }\end{array}$ & Yes & 35 & 87,5 \\
No & 5 & 12,5 \\
Have used of haven't used the interactive & Yes & 31 & 77,5 \\
multimedia in the learning process & No & 9 & 22,5 \\
Need or do not need the interactive multimedia & Yes & 39 & 97,5 \\
in the learning process & No & 1 & 2,5 \\
\hline
\end{tabular}

The table below states that the listening comprehension discourse is relevant to the competency target.

Table 2. Interactive multimedia data

\begin{tabular}{|c|c|c|c|c|c|c|c|c|}
\hline \multirow{2}{*}{ Indicators } & \multicolumn{5}{|c|}{ Scale } & \multirow{2}{*}{ Score } & \multirow{2}{*}{$\begin{array}{l}\text { Presentase Kualitas Materi } \\
(\%)\end{array}$} & \multirow{2}{*}{ Criteria } \\
\hline & 1 & 2 & 3 & 4 & 5 & & & \\
\hline Kesesuaian materi & 0 & 0 & 3 & 26 & 11 & 168 & 84 & Excellent \\
\hline Kejelasan petunjuk belajar & 0 & 1 & 5 & 21 & 13 & 166 & 83 & Excellent \\
\hline $\begin{array}{l}\text { Kemudahan memahami kalimat } \\
\text { pada teks }\end{array}$ & 0 & 1 & 11 & 19 & 9 & 156 & 78 & Good \\
\hline memahami & 0 & 1 & 13 & 17 & 9 & 154 & 77 & Good \\
\hline Ketepatan urutan penyajian & 0 & 4 & 10 & 19 & 7 & 149 & 75 & Good \\
\hline Kecukupan latihan & 1 & 1 & 15 & 17 & 6 & 146 & 73 & Good \\
\hline Kejelasan umpan balik & 0 & 1 & 13 & 16 & 10 & 155 & 78 & Good \\
\hline Bantuan belajar dengan program & 0 & 1 & 7 & 20 & 12 & 163 & 82 & Excellent \\
\hline Keindahan tampilan layar & 0 & 7 & 6 & 15 & 12 & 152 & 76 & Good \\
\hline Keterbacaan teks & 0 & 1 & 8 & 23 & 8 & 158 & 79 & Good \\
\hline Kualitas gambar dan animasi & 0 & 1 & 9 & 18 & 12 & 161 & 81 & Good \\
\hline Komposisi warna & 0 & 2 & 12 & 14 & 12 & 156 & 78 & Baik \\
\hline Navigasi & 1 & 3 & 6 & 22 & 8 & 153 & 77 & Good \\
\hline Daya dukung musik & 0 & 0 & 11 & 19 & 10 & 159 & 80 & Good \\
\hline Interaksi & 0 & 0 & 8 & 19 & 13 & 165 & 83 & Excellent \\
\hline Mean Score & & & & & & & 79,00 & Good \\
\hline
\end{tabular}

Descriptive statistics.

Table 3. Mean score and deviation score

\begin{tabular}{|c|c|c|c|c|c|c|c|}
\hline \multicolumn{4}{|c|}{ EXPERIMENTAL GROUP } & \multicolumn{4}{|c|}{ CONTROL GROUP } \\
\hline \multicolumn{2}{|c|}{ PRE-TES } & \multicolumn{2}{|c|}{ POST-TEST } & \multicolumn{2}{|c|}{ PRE-TEST } & \multicolumn{2}{|c|}{ POST-TEST } \\
\hline$X$ & $\mathrm{~S}$ & $X$ & $\mathrm{~S}$ & $X$ & $\mathrm{~S}$ & $X$ & $\mathrm{~S}$ \\
\hline 65 & 12,7 & 80 & 13,15 & 75 & 10,5 & 75,3 & 11,86 \\
\hline
\end{tabular}

\section{Conclusion}

As a conclusion, multimedia is necessary for the students to improve their learning activities on the subject of listening comprehension. It is significant to improve the students' listening comprehension at Mean score on the pre-test of experimental group is 65 with the higher score on 80 and the lowest score on 40 with deviation score 
on 12.7, while the mean score on the post-test is 80 with the higher score on 100 and the lowest score on 60 with deviation score on 13.15. Suggestions to this research are to make more time conducting in a longitudinal research project with more funds and developments on the progress of designing the multimedia according to the goal of the subject matter of listening comprehension in order to improve the students' listening comprhension. Experiment is absolutely needed in this research in more variables as a scientific method to show the reader in accurate and significant results of improving students' listening comprehension due to the development of multimedia to support the learning.

\section{References}

Brinkmann, S. (2008). Interviewing. In L. M. Given (Ed.), The Sage Encyclopedia of Qualitative Research Methods (pp. 470-472). Thousand Oaks, CA: SAGE Publications, Inc.

Brown, D. H. (2001). Teaching by Principles: An Interactive Approach to Language Pedagogy. New York: Longman.

Brown, G. (1990). Listening to Spoken English. New York: Longman.

Brown, H. D. (2003). Language Assessment: Principles and Classroom Practices. New York: Longman.

Brown, J. D. (2001). Using Surveys in Language Programs. Cambridge, UK: Cambridge University Press.

Burns, A. (2005). Action Research. In E. Hinkel (Ed.), Handbook of Research in Second Language Teaching and Learning (pp. 241-256). Mahwah, New Jersey: Lawrence Erlbaum Associates, Inc. Publishers.

Clark, D. (2000). Learning Styles. Retrieved January 08, 2009 from http://www.nwlink.com/ donclark/hrd/learning/styles.html\#mi

Dornyei, Z. (2003). Questionaires in Second Language Research: Construction, Administration, and Processing. Mahwah, New Jersey: Lawrence Erlbaum Associates, Inc.

Heinich, R. Al. (1996). Instructional Media and Technologies for Learning (5th ed). New Jersey: A Simon \& Schuster Company Engelewood Cliffs.

Joko Nurkamto. 2002. An Introduction to Classroom Action Research. Paper. Presented at a regional workshop for the English teachers of Madrasah Aliyah of Central Java in Madrasah AliyanNegeri Model Magelang, Central Java.

Jones, C., \& Fortescue, S. (1987). Using Computers in the Language Classroom. London: Longman.

Julien, H. (2008). Content Analysis. In L. M. Given (Ed.), The Sage Encyclopedia of Qualitative Research Methods (pp. 120-121). Thousand Oaks, CA: SAGE Publications, Inc.

McKechnie, L. E. F. (2008). Observational Research. In L. M. Given (Ed.) The Sage Encyclopedia of Qualitative Research Methods (pp. 573-576). Thousand Oaks, CA: SAGE Publications, Inc.

Morley, J. (2001). Aural Comprehension Instruction: Principles and Practices. In M. Celce-Murcia (Ed.), Teaching English as a Second or Foreign Language (3rd edition) (pp. 69-85). Ontario, Canada: Heinle \& Heinle.

Nation, I. S. P., \& Newton, J. (2009). Teaching ESL/EFL Listening and Speaking. New York: Routledge.

Nichols, R. G. (1974). Listening: Questions and Problems. Quarterly Journal of Speech, 33, 83-86. https://doi.org/10.1080/00335634709381268

Nunan, D. (1999). Second Language Teaching and Learning. Boston: Heinle\&Heinle Publishers.

Postovsky, V. (1977). Why not start speaking later? In M. Burt, H. Dulay, \& M. Finocchiaro (Eds.), Viewpoints on English as a Second Language. In Honor of James E. Alatis. New York: Regents Publishing Co.

Richards, J. C., \& Rodgers, T. (2001). Approaches and Methods in Language Teaching. New York: Cambridge University Press. https://doi.org/10.1017/CBO9780511667305

Richards, J. C. (1983). Listening Comprehension: Approach, Design, Procedure. TESOL Quarterly, 17, 219-239. https://doi.org/10.2307/3586651

Richards, J. C. (2008). Teaching Listening and Speaking: From Theory to Practice. New York: Cambridge University Press.

Richards, J. C. (2009). Second Thoughts on Teaching Listening. Retrieved July 27, 2009 from http://www.jackcrichards.com/ 
Richards, J. C., \& Schmidt, R. (2002). Longman Dictionary of Language Teaching and Applied Linguistics (3rd edition). Harlow: Pearson Education Limited.

Thanajaro, M. (2000). Using Authentic Materials to Develop Listening Comprehension in the English as a Second Language Classroom. Doctoral Disertation, unpublished, Virginia Polytechnic Institute and State University, Blacksburg, Virginia.

Vandergrift, L. (1999). Facilitating Second Language Listening Comprehension: Acquiring Successful Srategies. ELT Journal, 53(3), 168-175. https://doi.org/10.1093/elt/53.3.168

\section{Copyrights}

Copyright for this article is retained by the author(s), with first publication rights granted to the journal.

This is an open-access article distributed under the terms and conditions of the Creative Commons Attribution license (http://creativecommons.org/licenses/by/4.0/). 